\title{
Review Paper: Effects of Virtual Reality Therapy on the Balance and Health-Related Quality of Life of Patients With Stroke: A Systematic Review
}

\author{
Hajra Ameer Shaikh ${ }^{1 *}$, Fouzia Hussain ${ }^{1}$, Darshan Kumar ${ }^{2}$ (D) \\ 1. Department of Physiotherapy, Ziauddin University, Karachi, Pakistan. \\ 2. Department of Physiotherapy, Faculty of physiotherapy, Jinnah Post Graduate Medical Centre, Karachi, Pakistan.
}

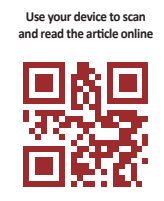

Cftation: Ameer Shaikh H, Hussain F, Kumar D. Effects of Virtual Reality Therapy on the Balance and Health-Related Quality of Life of Patients With Stroke: A Systematic Review. Journal of Modern Rehabilitation. 2020; 14(1):1-10. http://dx.doi. org/10.32598/JMR.14.1.1

doi ihttp://dx.doi.org/10.32598/JMR.14.1.1

Article info:

Received: 07 Jul 2019

Accepted: 23 Nov 2019

Available Online: 01 Jan 2020

\section{Keywords:}

Balance, Health-related Quality of Life, Physiotherapy, Stroke, Rehabilitation, Virtual Reality Therapy

\begin{abstract}
A B STRACT
Introduction: Stroke is one of the leading causes of death worldwide. Despite the glowing advancement of Virtual Reality Therapy (VRT), clear evidence about its effectiveness in stroke is still scarce. Hence it is essential to review the current information to provide up-to-date insight. Therefore the aim of this review is to evaluate the effects of VRT on the balance and Health-related Quality of Life (HRQoL) in patients with stroke.
\end{abstract}

Data Sources: A literature search was done in Google Scholar, PEDro, Cochrane Library, Medline, Web of Science, and PubMed databases.

Eligibility Criteria: We performed a systematic review of randomized controlled trials published from June 2014 to January 2020, evaluating the effects of VRT on the balance and/ or HRQoL in stroke. Fourteen eligible trials were analyzed, of which, 7 studies focused on balance and 7 on HRQoL.

Quality Appraisal: Methodological quality and risk of bias were assessed using the Cochrane tool.

Results: Most of the trials supported the effectiveness of VRT in improving balance and HRQoL. However, few trials reported similar improvements in HRQoL using VRT via Nintendo WiiTM games and conventional physiotherapy.

Conclusions: High to moderate evidence supports the effectiveness of VRT use in improving balance and HRQoL in stroke survivors. 


\section{Introduction}

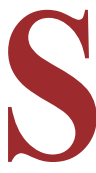

troke has been reported as one of the leading causes of disability and death globally [1]. In 2010, the worldwide prevalence of stroke was reported to be 33 million [2].

In recent years, Virtual Reality Therapy (VRT) has been introduced in the stroke rehabilitation program [3]. VRT has been popularized and recommended in stroke management [4-6]. Virtual Reality (VR) is defined as "an advanced type of human-computer interface that allows the user to interact and immersed in a computer-generated environment in a naturalistic design" [7]. VR-based rehabilitation has been proven to enhance goal-orientated training that significantly impacts patients' adherence to exercise programs $[8,9]$. Previous studies report that VR makes rehabilitation programs more attractive and engaging than traditional treatment programs. Hence it plays a great role in adhering to a physiotherapy treatment program for a prolonged duration [10].

A 2012 study reports that balance is essential to perform activities of daily living (ADL) [11]. Coordination and balancing impairments are the main complications of stroke patients [12]. The weakness of legs' muscles profoundly affects walking and balance [13]. One study also reports balance to be an essential factor for gait recovery [14]. Another study found that the prefrontal cortex is the most vital brain part in controlling balance [15].

Research conducted by Lai SM et al. suggested that stroke status can significantly impact the ADLs and social participation of patients [16]. The patient's independence in ADLs and improvement in health-related quality of life (HRQoL) are the essential goals of post-stroke physiotherapy.

Despite glowing advances in the rehabilitation of stroke, yet a considerable portion of stroke survivors are living with significantly reduced HRQoL, especially in the domain of mobility and ADLs [17]. Previously conducted two systematic reviews and meta-analysis in 2016 and 2017 reported that VRT is effective in improving balance compared with conventional therapy in stroke $[18,19]$. However, rigorous review regarding the effects of VRT on stroke is scarce. Therefore, this systematic review aims to critically evaluate the impact of VRT on balance and HRQoL in patients with stroke.

\section{Materials and Methods}

Study design

A systematic review was conducted on randomized controlled trials that assessed the effects of VRT on patients with stroke.

\section{Review protocol}

The review was conducted following the PRISMA (Preferred Reporting Items for Systematic Reviews and Meta-Analyses) recommendations [20].

\section{Criteria for eligibility}

Studies that met the following criteria were included: Study design must be a randomized controlled trial; clinically diagnosed hemorrhagic or ischemic stroke as the targeted population; trials evaluating balance or HRQoL as the outcome measure; trials analyzing/comparing the effects of VRT with an alternative intervention or no intervention; trials published from 2014 up to January 2020; and the article must be in English. Studies investigating the effects of rehabilitation other than the VR environment were excluded.

\section{Sources of information}

Six electronic databases that includes PEDro, Google Scholar, Cochrane Library, Web of Science, Medline, and PubMed were reviewed.

\section{Search strategy}

In January 2020, a systematic search was carried out using six different databases. Medical subject headings (MeSH) terms included "virtual reality therapy," "gaming," stroke," "cerebrovascular accident," "QOL," "balance training," "HRQOL," "physiotherapy," and "rehabilitation." Titles and/or abstracts were reviewed, and those articles not meeting eligibility criteria were excluded. The remaining articles were studied in full to evaluate their suitability in consideration with the PRISMA guidelines.

\section{Study selection}

Initial screening was carried out based on the titles and/ or abstracts by two reviewers (H.A.S. and F.H.). Then, the detailed evaluation of full text and analysis against the eligibility criteria was performed by two reviewers (D.K. and H.A.S.). The primary search sought a total of 252 studies; some studies were not freely accessible, 
and others were irrelevant. Finally, 14 trials that met the eligibility criteria were reported in the review of which, seven studies evaluated the effect of VRT on balance and seven on HRQoL.

\section{Extraction of data}

The information like year of publication, location, sample size, intervention applied, frequency, duration of follow-up, outcome measures, and main findings were extracted from the included trials.

\section{Risk of bias}

The risk of bias was evaluated using the Cochrane tool [21]. It evaluates biases in various manners, which include random allocation, allocation concealment, blinding of participants and outcome assessment, incomplete outcome data, selective reporting, and other factors.

\section{Results}

\section{Selection of studies}

The initial screening identified 252 records in different databases. A total of 152 articles were excluded based on titles and/or abstracts, not meeting the inclusion criteria and duplication. Also, 25 trials were retrieved to review in full, of which 14 RCTs were analyzed in this review [22-35]. Figure 1 shows the PRISMA flow diagram of the selection strategy of the trials.

\section{Study characteristics:}

All 14 trials involved a total of 759 stroke patients and investigated the effects of VRT on balance and/or HRQoL in stroke patients. All trials were conducted from June 2014 to January 2020.

Results of the studies related to the effects of VRT on balance in stroke

The sample size of the seven studies related to the effects of VRT on balance in stroke was 234, with few trials reported sample size calculation. The follow-up duration of the trials ranged from 1 to 3 months. However, most studies used the Berg Balance Scale (BBS) and Timed Up and Go (TUG) tests as outcome measures [23-28] (Table 1).

A recent study conducted by Lisa et al. [22] reported that VRT with or without trunk movement shows similar improvement in sitting balance. Various trials reported significant improvement in the balance of stroke survivors by VRT using Jintronix rehabilitation, Motion Rehab AVE 3D, Canoe games, Virtual Reality Reflection Therapy (VRRT), and 3D virtual environment compared with the Conventional Physiotherapy Therapy (CPT) [23-27]. Also, a trial conducted in Canada by McEwen et al. [28] reported that VRT using IREX VR games (interactive rehabilitation exercise software) was significantly effective in improving both sitting and standing balance in stroke patients (Table 1).

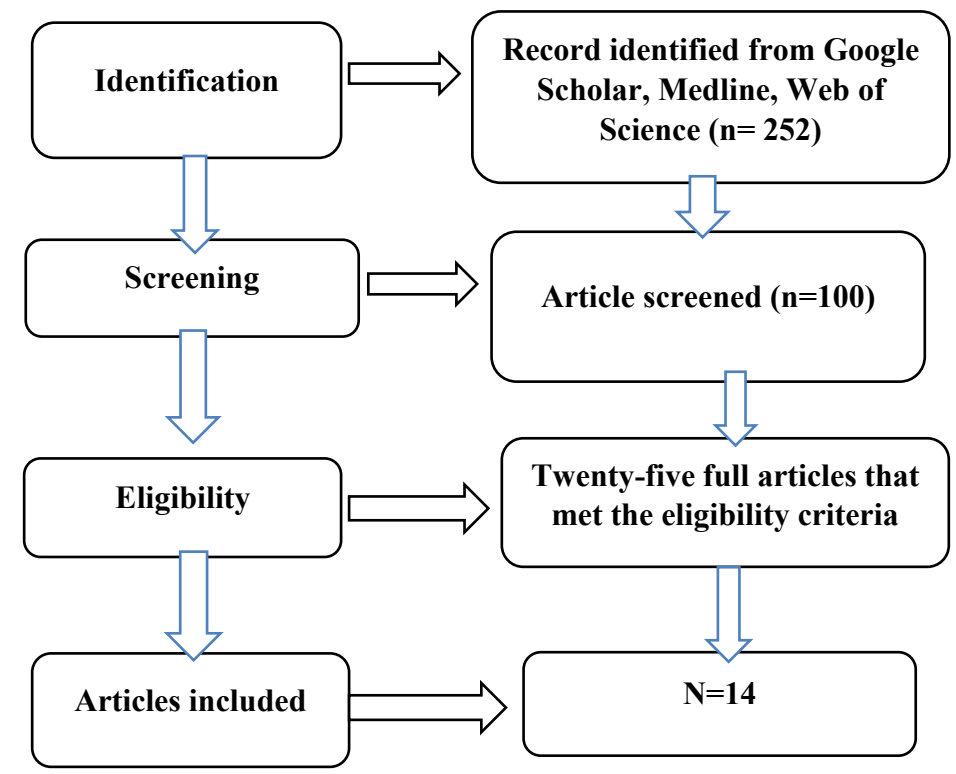

Figure 1. The selection process of studies 
Table 1. Summary of the trials related to the effects of VRT on balance

\begin{tabular}{|c|c|c|c|c|c|c|c|}
\hline Authors & $\begin{array}{l}\text { Lisa et al. } \\
\text { [22] }\end{array}$ & $\begin{array}{c}\text { Sheehy et al. } \\
\text { [23] }\end{array}$ & $\begin{array}{l}\text { Henrique et } \\
\text { al. [24] }\end{array}$ & $\begin{array}{c}\text { Lee et al. } \\
\text { [25] }\end{array}$ & In et al. [26] & $\begin{array}{c}\text { Lloréns et al. } \\
\text { [27] }\end{array}$ & $\begin{array}{l}\text { McEwen et } \\
\text { al. [28] }\end{array}$ \\
\hline Year & 2020 & 2019 & 2019 & 2016 & 2016 & 2015 & 2014 \\
\hline $\begin{array}{l}\text { Study } \\
\text { design }\end{array}$ & RCT & RCT & RCT & A pilot RCT & RCT & RCT & RCT \\
\hline Location & Canada & Canada & Brazil & South Korea & South Korea & Spain & Canada \\
\hline Sample size & $\begin{array}{c}n=69,(E G=33 \\
\text { and } C G=36)\end{array}$ & $\begin{array}{c}\mathrm{n}=20,(\mathrm{EG}=10 \\
\text { and } \mathrm{CG}=10)\end{array}$ & $\begin{array}{c}\mathrm{n}=31,(\mathrm{EG}=16 \\
\text { and } \mathrm{CG}=15)\end{array}$ & $\begin{array}{l}\mathrm{n}=10,(E G=5 \\
\text { and } C G=5)\end{array}$ & $\begin{array}{c}n=25,(E G=13 \\
\text { and } C G=12)\end{array}$ & $\begin{array}{c}n=20,(E G=10 \\
\text { and } C G=10)\end{array}$ & $\begin{array}{c}n=59,(E G=30 \\
\text { and } C G=29)\end{array}$ \\
\hline $\begin{array}{l}\text { Interven- } \\
\text { tion }\end{array}$ & 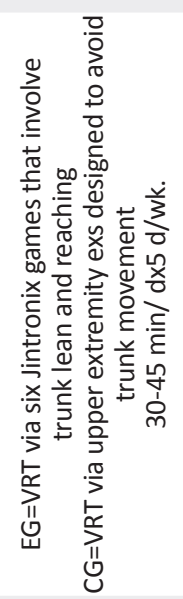 & 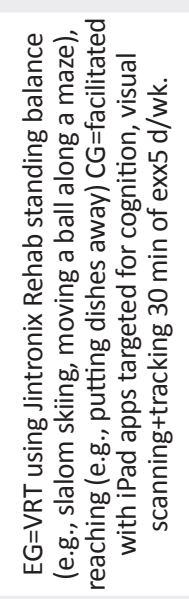 & 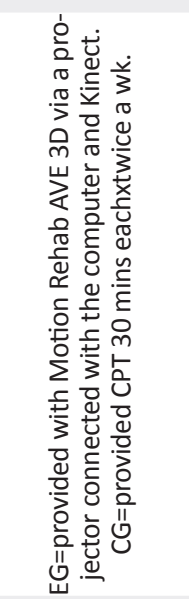 & 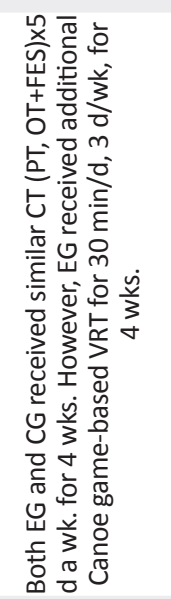 & 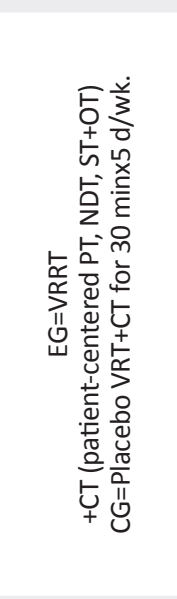 & 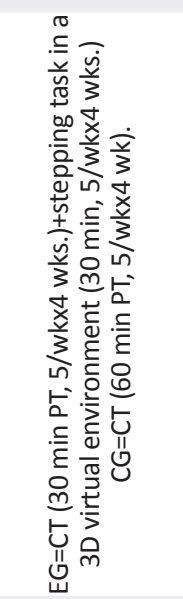 & 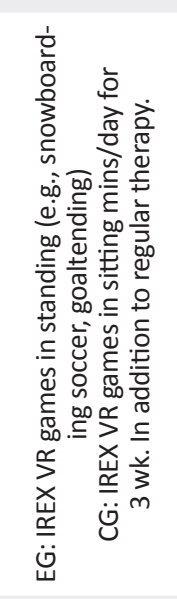 \\
\hline $\begin{array}{l}\text { Duration of } \\
\text { follow-up }\end{array}$ & 1 Month & 6 weeks & 3 Months & 2 Months & 1 Month & 1 Month & 1 Month \\
\hline $\begin{array}{l}\text { Outcome } \\
\text { measure }\end{array}$ & FIST and OSS & $\begin{array}{l}\text { BBS, TUG test } \\
\text { and CB \& M }\end{array}$ & BBS & $\begin{array}{l}\text { BBS and } \\
\text { TUG }\end{array}$ & $\begin{array}{l}\text { BBS, TUG, } \\
\text { and FRT }\end{array}$ & $\begin{array}{l}\text { BBS, Tinetti } \\
\text { POMA, and } \\
\text { BBA }\end{array}$ & TUG \\
\hline $\begin{array}{l}\text { Main find- } \\
\text { ings }\end{array}$ & $\begin{array}{l}\text { A similar im- } \\
\text { provement } \\
\text { was founded } \\
\text { in siting bal- } \\
\text { ance in both } \\
\text { groups. }\end{array}$ & $\begin{array}{c}\text { Significant } \\
\text { improvement } \\
\text { in BBS in EG } \\
\text { as compared } \\
\text { to CG. }\end{array}$ & $\begin{array}{c}\text { Significant } \\
\text { improvement } \\
\text { in BBS in EG } \\
\text { as compare } \\
\text { to CG }\end{array}$ & $\begin{array}{l}\text { BBS and } \\
\text { TUG scores } \\
\text { were statisti- } \\
\text { cally greater } \\
\text { in the EG } \\
\text { than in the } \\
\text { CG. }\end{array}$ & $\begin{array}{l}\text { Considerable } \\
\text { improve- } \\
\text { ment in the } \\
\text { balance of } \\
\text { the VRRT } \\
\text { group was } \\
\text { found }\end{array}$ & $\begin{array}{c}\text { Greater } \\
\text { improvement } \\
\text { was reported } \\
\text { in EG com- } \\
\text { pared to CG. }\end{array}$ & $\begin{array}{l}\text { Both groups } \\
\text { reported } \\
\text { improvement } \\
\text { in balance. }\end{array}$ \\
\hline
\end{tabular}

RCT: randomized controlled trial; EG: experimental group; CG: control group; VRT: Virtual Reality Therapy; CPT: conventional physiotherapy therapy; PT: physiotherapy; OT: occupational therapy; FES: functional electrical stimulation; VRRT: Virtual Reality Reflection Therapy; NDT: neuro-developmental technique; IREX: interactive rehabilitation exercise software; VR: virtual reality; ST, speech therapy; FIST, function in the sitting test; OSS, Ottawa Sitting Scale; BBS, Berg Balance Scale; TUG, Timed Up-And-Go tests; CB \& M: Community Balance And Mobility Scale; FRT: functional reaching test; POMA: performance-oriented mobility assessment; BBA: Brunel Balance Assessment.

Results of the studies related to the effects of VRT on HRQoL in stroke

The sample size of the seven studies related to the impact of VRT on HRQoL in stroke was 525. The follow-up duration of the studies ranged from one to six months. Trails reported that VRT using RAPAEL Smart Board $^{\mathrm{TM}}$, RAPAEL Smart Glove ${ }^{\mathrm{TM}}$, and Gait Real-time Analysis Interactive Lab (GRAIL) significantly improved HRQoL compared to the CPT [29, 30, 33]. However, Zheng et al. found that the addition of repetitive transcranial magnetic stimulation (rTMS) together with
VRT more significantly improved HRQoL compared to VRT alone [34]. Lee et al. reported similar improvement in QoL via VRT, either performed individualized or group-based [32]. Two studies showed homogeneous improvement in QoL by VRT via Nintendo WiiTM (NW) games and CPT [31, 34] (Table 2).

Risk of bias within Studies and quality appraisal:

All trials had a low risk of bias in random allocation. Only one study showed a low risk of bias in all the measures [34]. In the majority of the trials, a high risk of bias 
Table 2. Summary of the trials related to the effects of VRT on HRQoL

\begin{tabular}{|c|c|c|c|c|c|c|c|c|}
\hline $\begin{array}{l}n \\
\frac{n}{0} \\
\frac{5}{2} \\
\frac{1}{\alpha}\end{array}$ & ֻ స & $\begin{array}{l}\frac{c}{000} \\
\frac{00}{y} \\
\frac{d}{0} \\
\frac{\partial}{\partial} \\
\dot{\nu}\end{array}$ & Location & $\begin{array}{l}\text { Sample } \\
\text { size }\end{array}$ & Intervention & $\begin{array}{l}\text { Duration } \\
\text { of follow- } \\
\quad \text { up }\end{array}$ & $\begin{array}{l}\text { Outcome } \\
\text { measure }\end{array}$ & $\begin{array}{l}\text { Main } \\
\text { finding }\end{array}$ \\
\hline 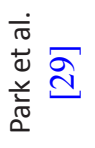 & 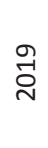 & 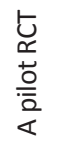 & $\begin{array}{l}\text { South } \\
\text { Korea }\end{array}$ & $\begin{array}{c}\mathrm{n}=26 \\
(\mathrm{EG}=13 \\
\text { and } \\
\mathrm{CG}=13)\end{array}$ & $\begin{array}{c}E G=V R T \text { via Rapael Smart Board }{ }^{\mathrm{TM}} \text { for } \\
30 \text { mins } C G=C P T \text { targeted to recover } \\
\text { AROM and co-ordination of the up- } \\
\text { per limbs for } 5 \mathrm{~d} / \text { wk., } \mathrm{x} 4 \text { wks. }\end{array}$ & 1 Month & SIS score & $\begin{array}{l}\text { VRT via RAPAEL } \\
\text { Smart Board }{ }^{\mathrm{M}} \text { is } \\
\text { effective in im- } \\
\text { proving HRQoL }\end{array}$ \\
\hline 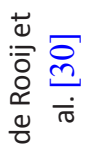 & ్ㅗㅁ & 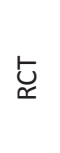 & $\begin{array}{l}\text { Breda, } \\
\text { The Neth- } \\
\text { erlands }\end{array}$ & $\begin{array}{l}\mathrm{n}=26 \\
(\mathrm{EG}=13 \\
\text { and } \\
\mathrm{CG}=13)\end{array}$ & $\begin{array}{c}E G=\text { Undergo VRT on GRAIL } \\
C G=\text { Undergo non-VRT (conventional } \\
\text { treadmill training+functional gait exs) } \\
230 \text {-min sessions per wk.x6 wks. }\end{array}$ & 3 Months & SS-QOL & $\begin{array}{l}\text { VRT via GRAIL } \\
\text { significantly im- } \\
\text { proves HRQoL as } \\
\text { compare to CPT. }\end{array}$ \\
\hline $\begin{array}{l}\overrightarrow{\bar{n}} \\
\frac{\dot{\pi}}{\pi} \\
\frac{0}{0} \\
\frac{.0}{2}\end{array}$ & 궁 & $\underset{ð}{\longleftarrow}$ & The UK & $\begin{array}{c}\mathrm{n}=235 \\
(\mathrm{EG}=117 \\
\text { and } \\
\mathrm{CG}=118)\end{array}$ & $\begin{array}{c}\text { EG=NWTM sports } \\
\text { games (bowling, golf, baseball, and } \\
\text { tennis) CG=patient centered arm } \\
\text { exs (based on graded repetitive arm } \\
\text { supplementary Program) All patients } \\
\text { underwent warm-up exsx15 mins } \\
\text { and done exs for } 45 \mathrm{~min} / \mathrm{dx} 6 \text { wks. }\end{array}$ & 6 Months & $\begin{array}{c}\text { SIS score } \\
\text { and EQ- } \\
\text { 5D 3L }\end{array}$ & $\begin{array}{l}\text { All patients re- } \\
\text { ported significant } \\
\text { improvement } \\
\text { in QOL. Hence } \\
\text { WiiTM was not } \\
\text { superior to arm } \\
\text { exs at home. }\end{array}$ \\
\hline 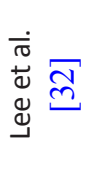 & $\begin{array}{l}0 \\
\stackrel{\nu}{0}\end{array}$ & 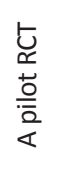 & $\begin{array}{l}\text { South } \\
\text { Korea }\end{array}$ & $\begin{array}{c}\mathrm{n}=26 \\
(\mathrm{EG}=13 \\
\text { and } \\
(\mathrm{CG}=13)\end{array}$ & $\begin{array}{l}\text { EG=VRG (individualized games involv- } \\
\text { ing upper limbs movement in differ- } \\
\text { ent planes) } \mathrm{CG}=\mathrm{GG} \text { similar therapy } \\
\text { protocol as VRG but in a group. Thirty } \\
\text { mins rehab program } 3 \mathrm{~d} / \text { wks. }\end{array}$ & 2 Months & SF-12 & $\begin{array}{l}\text { Homogeneous } \\
\text { improvement in } \\
\text { HRQoL between } \\
\text { groups. }\end{array}$ \\
\hline 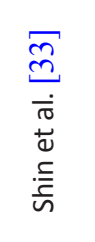 & $\begin{array}{l}0 \\
\stackrel{\nu}{0}\end{array}$ & $\underset{ð}{\longleftarrow}$ & Korea & $\begin{array}{c}\mathrm{n}=46 \\
(\mathrm{EG}=24 \\
\text { and } \\
\mathrm{CG}=22)\end{array}$ & $\begin{array}{l}\text { EG=RAPAEL Smart Glove } \text { TM }^{\mathrm{M}} \text { interven- } \\
\text { tion CG=conventional therapy involv- } \\
\text { ing similar movements of the distal } \\
\text { upper limb. Both groups undergo } \\
\text { treatment for } 30 \mathrm{~min} / \text { day+OT daily } \\
\text { for } 30 \text { minx } 4 \text { wks. }\end{array}$ & 1 Month & SIS score & $\begin{array}{l}\text { VRT, together } \\
\text { with OT, more } \\
\text { effectively } \\
\text { improves HRQoL } \\
\text { as compare to } \\
\text { conventional } \\
\text { rehab. }\end{array}$ \\
\hline 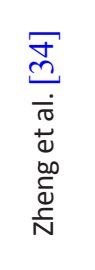 & 吕 & $\underset{\check{\longleftarrow}}{\longleftarrow}$ & China & $\begin{array}{l}\mathrm{n}=112 \\
(\mathrm{EG}=58 \\
\text { and } \\
\mathrm{CG}=54)\end{array}$ & $\begin{array}{c}\text { EG=NW games (tennis, soc- } \\
\text { cer, boxing, and hula-hoop+TAU } \\
\text { CG=CPT (upper and lower extrem- } \\
\text { ity stretching and trunk, passive, } \\
\text { active-assisted, and active-resisted } \\
\text { mobilization+balance reactions with } \\
\text { rapid shifts } 60 \text { mins therapy sessions } \\
\text { twice a wks. }\end{array}$ & 2 Months & SF-36 QOL & $\begin{array}{l}\text { Both CPT and NW } \\
\text { groups homoge- } \\
\text { neously improve } \\
\text { HRQoL }\end{array}$ \\
\hline 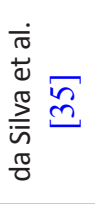 & 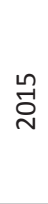 & $\underset{\longleftarrow}{\longleftarrow}$ & Brazil & $\begin{array}{l}\mathrm{n}=30 \\
(\mathrm{EG}=15 \\
\text { and } \\
\mathrm{CG}=15)\end{array}$ & $\begin{array}{l}\text { All patients underwent standard } \\
\text { therapy ( } 30 \text { min OT+3o mins VRT via } \\
\text { BioMaste system) EG=received rTMS } \\
\text { (1.0 Hz, } 90 \% \text { rMT, } 1800 \text { pulses)VRT } \\
\text { CG=received sham rTMS and VRT for } \\
30 \text { min, } 6 \text { times per wks, } 24 \text { sessions. }\end{array}$ & 1 Month & SF-36 QOL & $\begin{array}{l}\text { VRT+rTMS sig- } \\
\text { nificantly improve } \\
\text { HRQoL as com- } \\
\text { pare to only VRT }\end{array}$ \\
\hline
\end{tabular}

RCT: randomized controlled trial; EG: experimental group; CG: control group; VRT: Virtual Reality Therapy; CPT: conventional physiotherapy therapy; VRT: Virtual reality therapy; GRAIL: Gait real-time analysis interactive lab; NW: Nintendo Wii; VRG: VR-based rehabilitation group; GG: group-based rehabilitation group; OT: occupational therapy; rTMS: repetitive transcranial magnetic stimulation; rMT: resting motor threshold; SIS: stroke impact scale; SS-QOL: stroke-specific quality of life scale; EQ-5D: EuroQol-5 dimension; SF-12: 12-item short-form health survey; QOL: quality of life; HRQoL: health-related quality of life.

regarding allocation concealment was found [22, 24-26, $28,31]$. Nine trials reported a low risk of bias in blinding of participants [23, 27-34]. The risk of bias of some stud- ies could not be determined from the method defined for other biases $[25,27,30]$ (Table 3 ). 
Table 3. Cochrane summary of the risk of bias

\begin{tabular}{|c|c|c|c|c|c|c|c|c|}
\hline $\begin{array}{l}\text { Risk of } \\
\text { Bias }\end{array}$ & $\begin{array}{c}\text { Randomized } \\
\text { Controlled } \\
\text { Trials }\end{array}$ & $\begin{array}{l}\text { Random } \\
\text { Allocation }\end{array}$ & $\begin{array}{l}\text { Allocation } \\
\text { Conceal- } \\
\text { ment }\end{array}$ & $\begin{array}{l}\text { Participants } \\
\text { Blinding }\end{array}$ & $\begin{array}{l}\text { Outcome } \\
\text { Assessment } \\
\text { Blinding }\end{array}$ & $\begin{array}{l}\text { Incomplete } \\
\text { Outcome } \\
\text { Data }\end{array}$ & $\begin{array}{l}\text { Selective } \\
\text { Report- } \\
\text { ing }\end{array}$ & $\begin{array}{l}\text { Other } \\
\text { Biases }\end{array}$ \\
\hline \multirow{7}{*}{ 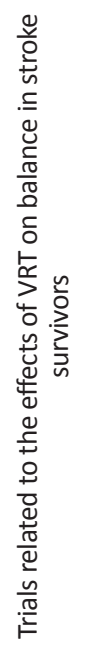 } & Lisa et al. [22] & + & - & - & + & + & + & - \\
\hline & $\begin{array}{c}\text { Sheehy et al. } \\
\text { [23] }\end{array}$ & + & + & + & + & - & - & - \\
\hline & $\begin{array}{l}\text { Henrique et } \\
\text { al. [24] }\end{array}$ & + & - & - & - & + & + & + \\
\hline & $\begin{array}{l}\text { Lee } \mathrm{M} \text { et al. } \\
\quad[25]\end{array}$ & + & - & - & - & + & + & $?$ \\
\hline & In et al. [26] & + & - & - & + & + & + & + \\
\hline & $\begin{array}{l}\text { Lloréns et al. } \\
\text { [27] }\end{array}$ & + & + & + & + & + & + & $?$ \\
\hline & $\begin{array}{c}\text { McEwen et al. } \\
{[28]}\end{array}$ & + & - & + & + & + & $?$ & + \\
\hline \multirow{7}{*}{ 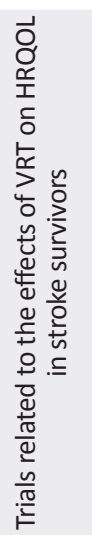 } & Park et al. [29] & + & + & + & + & + & + & + \\
\hline & $\begin{array}{c}\text { de Rooij et al. } \\
{[30]}\end{array}$ & + & + & + & + & $?$ & + & $?$ \\
\hline & Adie et al. [31] & + & - & - & + & + & + & - \\
\hline & Lee et al. [32] & + & + & + & + & + & $?$ & - \\
\hline & Shin et al. [33] & + & + & + & - & + & + & - \\
\hline & $\begin{array}{c}\text { Zheng et al. } \\
\text { [34] }\end{array}$ & + & + & + & + & + & + & + \\
\hline & $\begin{array}{c}\text { da Silva et al. } \\
\text { [35] }\end{array}$ & + & + & + & + & + & + & - \\
\hline
\end{tabular}

(-) Indicates a high risk of bias; (+) Indicates a low risk of bias; (?) Indicates that the defined methodology cannot ensure the risk of bias Higgins et al. [21].

\section{Synthesis of results}

Most trials support the effectiveness of VRT in improving balance and HRQoL. However, few trials reported similar improvement using VRT via NWTM games and CPT in improving HRQoL.

\section{Discussion}

This systematic review has critically evaluated the randomized controlled trials conducted over the past seven years (2014-2020) to assess the effects of VRT on balance and HRQoL in stroke patients. This comprehensive review consists of 14 eligible trials, of which seven evaluated the effectiveness of VRT on balance and seven on HRQoL with a total sample size of 759 stroke survivors.
A study conducted by Brumels KA et al. reported that conventional balance training results with poor adherence and interest in a rehabilitation program would lead to poor recovery [36]. However, VRT, with its attractiveness and engagement, helps the patient to focus on the exercise and recover faster. This evidence is supported by various trials that reported a considerable improvement in the balance of stroke patients using VRT via Jintronix rehabilitation, Motion Rehab AVE 3D, Canoe games, VRRT, and 3D virtual environment compared with CPT [23-27]. Based on the efficacy of VRT, Pietrzak et al. recommended in their study that emphasis should be placed on its use in stroke rehab program [37].

Trials conducted by Adie K et al. and Da Silva et al. reported homogeneous improvement in QoL between 
VRT via NWTM games and CPT [31, 34]. However, these results are contradicted by Morone $\mathrm{G}$ et al. trial reporting that balance training performed via video game-based treatment, i.e., Wii Fit, in addition to the conventional therapy, was found to be useful for improving balance compared to CPT alone in patients affected by stroke [38].

Imam B et al. claimed that the beneficial effects of VRT in stroke patients could be the influence of multisensory involvement, i.e., visual and auditory feedback and the motivational aspect of the VR environment [39]. Another study supported this finding and stated that sensory feedback allows the central nervous system to control orientation and body position [40]. This finding contradicts an essential feature of exercises presented in neuro-rehab, i.e., continuous repetition facilitates speedy functional recovery [41].

The evidence remains of moderate quality as the risk of bias of most trials was unclear due to poor reporting style. Approximately $50 \%$ of the trials reported a high risk of bias in allocation concealment [22, 24-26, 28, 31 ; likewise, the majority of the studies reported a high risk of bias regarding other issues [22, 23, 30-34].

The included trials reported considerable variation in the type of VRT intervention used, time, frequency, outcome measure, and setting. The duration of follow-up ranged from one to six months. Hence it is difficult to turn these preliminary findings into generalized recommendations regarding its efficacy. However, most studies support the effectiveness of VRT in improving balance and HRQoL in stroke and that this tool has the potential to motivate and facilitate feedback-rich rehabilitation. Furthermore, no trial reported adverse effects suggesting that the VRT is a safe treatment for stroke survivors.

In consideration to the conceptual framework of the International Classification of Functioning (ICF), Disability and Health, this review reveals that VRT plays an essential role in enhancing the activity limitation (balance) and participation restriction (HRQoL) of a critical health condition (stroke).

One of the strengths of this review is focusing on the use of RCTs (2014 to January 2020) with valid and reliable instruments to measure outcomes and analyze the results.

Although the proposed review is of tremendous clinical significance in the domain of neuro-rehabilitation and, particularly to stroke, some limitations should be ad- dressed. A considerable variety of VR interventions were categorized under the same term (VRT). Furthermore, acute, subacute, and chronic strokes were not separately evaluated. The sample size and methodological quality of some studies were found inadequate.

Further high-quality studies with larger sample sizes are needed to clearly understand which type of VRT is most effective, and what will be the optimal time and intensity to achieve a better outcome in different stages of stroke.

\section{Conclusion}

High to moderate evidence supports the effectiveness of VRT in improving balance and HRQoL in stroke survivors. However, due to insufficient evidence, a robust and reliable conclusion cannot be drawn. The finding of this review is essential in clinical practice and serves as a preliminary step in providing constructive criticism to upgrade the methodology of future studies.

\section{Ethical Considerations}

\section{Compliance with ethical guidelines}

Ethical principles were considered in all reported trials. Furthermore, informed consent was taken, and confidentiality was maintained.

\section{Funding}

This systematic review received no external funding.

\section{Authors contributions}

Conceptualization and Writing original draft: Hajra Ameer Shaikh substantially; Data collection: Fouzia Hussain; Writing-review \& Editing: Darshan Kumar.

\section{Conflict of interest}

The authors declared no conflicting interests.

\section{References}

[1] Vorkas PA, Shalhoub J, Lewis MR, Spagou K, Want EJ, Nicholson JK, et al. Metabolic phenotypes of carotid atherosclerotic plaques relate to stroke risk: An exploratory study. European Journal of Vascular and Endovascular Surgery. 2016; 52(1):5-10. [DOI:10.1016/j.ejvs.2016.01.022] [PMID] 
[2] Feigin VL, Forouzanfar MH, Krishnamurthi R, Mensah GA, Connor M, Bennett DA, et al. Global and regional burden of stroke during 1990-2010: Findings from the global burden of disease study 2010. The Lancet. 2014; 383(9913):245-55. [DOI:10.1016/S0140-6736(13)61953-4]

[3] Kim JH, Jang SH, Kim CS, Jung JH, You JH. Use of virtual reality to enhance balance and ambulation in chronic stroke: A double-blind, randomized controlled study. American Journal of Physical Medicine \& Rehabilitation. 2009; 88(9):693-701. [DOI:10.1097/PHM.0b013e3181b33350] [PMID]

[4] Merians AS, Jack D, Boian R, Tremaine M, Burdea GC, Adamovich SV, et al. Virtual reality-augmented rehabilitation for patients following stroke. Physical Therapy. 2002; 82(9):898915. [DOI:10.1093/ptj/82.9.898] [PMID]

[5] You SH, Jang SH, Kim YH, Hallett M, Ahn SH, Kwon YH, et al. Virtual reality-induced cortical reorganization and associated locomotor recovery in chronic stroke: An experimenter-blind randomized study. Stroke. 2005; 36(6):1166-71. [DOI:10.1161/01.STR.0000162715.43417.91] [PMID]

[6] Lam YS, Man DW, Tam SF, Weiss PL. Virtual reality training for stroke rehabilitation. NeuroRehabilitation. 2006; 21(3):24553. [DOI:10.3233/NRE-2006-21308] [PMID]

[7] Schultheis MT, Rizzo AA. The application of virtual reality technology in rehabilitation. Rehabilitation Psychology. 2001; 46(3):296-311. [DOI:10.1037/0090-5550.46.3.296]

[8] Levin MF, Weiss PL, Keshner EA. Emergence of virtual reality as a tool for upper limb rehabilitation: Incorporation of motor control and motor learning principles. Physical therapy. 2015; 95(3):415-25. [DOI:10.2522/ptj.20130579] [PMID] [PMCID]

[9] Laver KE, Lange B, George S, Deutsch JE, Saposnik G, Crotty M. Virtual reality for stroke rehabilitation. Cochrane Database of Systematic Reviews. 2017; 2017(11):CD008349. [DOI:10.1002/14651858.CD008349.pub4] [PMID] [PMCID]

[10] Lewis GN, Rosie JA. Virtual reality games for movement rehabilitation in neurological conditions: How do we meet the needs and expectations of the users? Disability and Rehabilitation. 2012; 34(22):1880-6. [DOI:10.3109/09638288.2012 .670036] [PMID]

[11] Kang HK, Chung YJ. Effects of treadmill training with real optic flow scene on balance and balance self-efficacy in individuals following stroke: A pilot randomized controlled trial. Physical Therapy Rehabilitation Science. 2012; 1(1):33-9. http:// kmbase.medric.or.kr/KMID/1012020120010010033

[12] Minet LR, Peterson E, von Koch L, Ytterberg C. Occurrence and predictors of falls in people with stroke: Six-year prospective study. Stroke. 2015; 46(9):2688-90. [DOI:10.1161/ STROKEAHA.115.010496] [PMID]

[13] Langhorne P, Coupar F, Pollock A. Motor recovery after stroke: A systematic review. The Lancet Neurology. 2009; 8(8):741-54. [DOI:10.1016/S1474-4422(09)70150-4]

[14] Kollen B, van de Port I, Lindeman E, Twisk J, Kwakkel G. Predicting improvement in gait after stroke: A longitudinal prospective study. Stroke. 2005; 36(12):2676-80 [DOI:10.1161/01.STR.0000190839.29234.50] [PMID]

[15] Bolton DA, Brown KE, Mcllroy WE, Staines WR. Transient inhibition of the dorsolateral prefrontal cortex disrupts somatosensory modulation during standing balance as measured by electroencephalography. Neuroreport. 2012; 23(6):369-72 . [DOI:10.1097/WNR.0b013e328352027c] [PMID]

[16] Lai SM, Studenski S, Duncan PW, Perera S. Persisting consequences of stroke measured by the Stroke Impact Scale. Stroke. 2002; 33(7):1840-4. [DOI:10.1161/01. STR.0000019289.15440.F2] [PMID]

[17] López Espuela F, Portilla Cuenca JC, Leno Díaz C, Párraga Sánchez JM, Gamez-Leyva G, Casado Naranjo I. [Sex differences in long-term quality of life after stroke: Influence of mood and functional status (English-Spanish)]. Neurología (English Edition). 2019 June. [DOI:10.1016/j.nrleng.2017.10.002] [PMID]

[18] de Rooij IJM, van de Port IGL, Meijer JWG. Effect of virtual reality training on balance and gait ability in patients with stroke: Systematic review and meta-analysis. Physical Therapy. 2016; 96(12):1905-18. [DOI:10.2522/ptj.20160054] [PMID]

[19] Iruthayarajah J, McIntyre A, Cotoi A, Macaluso S, Teasell $R$. The use of virtual reality for balance among individuals with chronic stroke: A systematic review and meta-analysis. Topics in Stroke Rehabilitation. 2017; 24(1):68-79. [DOI:10.108 0/10749357.2016.1192361] [PMID]

[20] Moher D, Liberati A, Tetzlaff J, Altman DG. Preferred reporting items for systematic reviews and meta-analyses: The PRISMA statement. Annals of Internal Medicine. 2009; 151(4):264-9. [DOI:10.7326/0003-4819-151-4-20090818000135] [PMID]

[21] Higgins JP, Altman DG, Gøtzsche PC, Jüni P, Moher D, Oxman AD, et al. The Cochrane collaboration's tool for assessing risk of bias in randomised trials. BMJ. 2011;343:d5928. [DOI:10.1136/bmj.d5928] [PMID] [PMCID]

[22] Lisa S, Anne TH, Heidi S, Martin B, Christine Y, Hillel F. Sitting balance exercise performed using Virtual Reality training on a stroke rehabilitation inpatient service: A randomized controlled study. PM \& R. 2020 January. [DOI:10.1002/ pmrj.12331]

[23] Sheehy L, Taillon-Hobson A, Sveistrup H, Bilodeau M, Yang C, Welch V, et al. Home-based virtual reality training after discharge from hospital-based stroke rehabilitation: A parallel randomized feasibility trial. Trials. 2019; 20:333. [DOI:10.1186/s13063-019-3438-9] [PMID] [PMCID]

[24] Henrique PPB, Colussi EL, De Marchi ACB. Effects of exergame on patients' balance and upper limb motor function after stroke: A randomized controlled trial. Journal of Stroke and Cerebrovascular Diseases. 2019; 28(8):2351-7. [DOI:10.1016/j.jstrokecerebrovasdis.2019.05.031] [PMID]

[25] Lee MM, Shin DC, Song CH. Canoe game-based virtual reality training to improve trunk postural stability, balance and upper limb motor function in subacute stroke patients: A randomized controlled pilot study. Journal of Physical Therapy Science. 2016; 28(7):2019-24. [DOI:10.1589/jpts.28.2019] [PMID] [PMCID]

[26] In T, Lee K, Song C. Virtual Reality reflection therapy improves balance and gait in patients with chronic stroke: Randomized controlled trials. Medical Science Monitor. 2016; 22:4046-53. [DOI:10.12659/MSM.898157] [PMID] [PMCID]

[27] Lloréns R, Gil-Gómez JA, Alcañiz M, Colomer C, Noé E. Improvement in balance using a virtual reality-based stepping exercise: A randomized controlled trial involving in- 
dividuals with chronic stroke. Clinical Rehabilitation. 2015; 29(3):261-8. [DOI:10.1177/0269215514543333] [PMID]

[28] McEwen D, Taillon-Hobson A, Bilodeau M, Sveistrup H, Finestone H. Virtual Reality exercise improves mobility after stroke: An inpatient randomized controlled trial. Stroke. 2014; 45(6):1853-5. [DOI:10.1161/STROKEAHA.114.005362] [PMID]

[29] Park M, Ko MH, Oh SW, Lee JY, Ham Y, Yi H, et al. Effects of Virtual Reality-based planar motion exercises on upper extremity function, range of motion, and health-related quality of life: A multicenter, single-blinded, randomized, controlled pilot study. Journal of Neuroengineering and Rehabilitation. 2019; 16:122. [DOI:10.1186/s12984-019-0595-8] [PMID] [PMCID]

[30] de Rooij IJM, van de Port IG, Visser-Meily JMA, Meijer JWG. Virtual Reality gait training versus non-virtual reality gait training for improving participation in subacute stroke survivors: Study protocol of the ViRTAS randomized controlled trial. Trials. 2019; 20:89. [DOI:10.1186/s13063-0183165-7] [PMID] [PMCID]

[31] Adie K, Schofield C, Berrow M, Wingham J, Humfryes J, Pritchard C, et al. Does the use of Nintendo Wii SportsTM improve arm function? Trial of WiiTM in Stroke: A randomized controlled trial and economics analysis. Clinical Rehabilitation. 2017; 31(2):173-85. [DOI:10.1177/0269215516637893] [PMID]

[32] Lee M, Son J, Kim J, Pyun SB, Eun SD, Yoon B. Comparison of individualized virtual reality-and group-based rehabilitation in older adults with chronic stroke in community settings: A pilot randomized controlled trial. European Journal of Integrative Medicine. 2016; 8(5):738-46. [DOI:10.1016/j.eujim.2016.08.166

[33] Shin JH, Kim MY, Lee JY, Jeon YJ, Kim S, Lee S, et al. Effects of virtual reality-based rehabilitation on distal upper extremity function and health-related quality of life: A single-blinded, randomized controlled trial. Journal of Neuroengineering and Rehabilitation. 2016; 13:17. [DOI:10.1186/s12984-0160125-x] [PMID] [PMCID]

[34] Zheng CJ, Liao WJ, Xia WG. Effect of combined lowfrequency repetitive transcranial magnetic stimulation and virtual reality training on upper limb function in subacute stroke: A double-blind randomized controlled trail. Journal of Huazhong University of Science and Technology [Medical Sciences]. 2015; 35(2):248-54. [DOI:10.1007/s11596-015-14190] [PMID]

[35] da Silva Ribeiro NM, Ferraz DD, Pedreira É, Pinheiro Í, da Silva Pinto AC, Neto MG, et al. Virtual rehabilitation via Nintendo Wii ${ }^{\circledR}$ and conventional physical therapy effectively treat post-stroke hemiparetic patients. Topics in Stroke Rehabilitation. 2015; 22(4):299-305. [DOI:10.1179/107493571 4Z.0000000017] [PMID]

[36] Brumels KA, Blasius T, Cortright T, Oumedian D, Solberg B. Comparison of efficacy between traditional and video game based balance programs. Clinical Kinesiology. 2008; 62(4):2631. https://search.proquest.com/openview/5a8e5af88bde91 c8d9098d9f259cc36e/1?pq-origsite $=$ gscholar\&cbl=29722

[37] Pietrzak E, Pullman S, McGuire A. Using virtual reality and videogames for traumatic brain injury rehabilitation: A structured literature review. GAMES FOR HEALTH: Research,
Development, and Clinical Applications. 2014; 3(4):202-14. [DOI:10.1089/g4h.2014.0013] [PMID]

[38] Morone G, Tramontano M, Iosa M, Shofany J, Iemma A, Musicco M, et al. The efficacy of balance training with video game-based therapy in subacute stroke patients: A randomized controlled trial. BioMed Research International. 2014; 2014:580861. [DOI:10.1155/2014/580861] [PMID] [PMCID]

[39] Imam B, Jarus T. Virtual reality rehabilitation from social cognitive and motor learning theoretical perspectives in stroke population. Rehabilitation Research and Practice. 2014; 2014:594540. [DOI:10.1155/2014/594540] [PMID] [PMCID]

[40] Lord SE, Rochester L, Weatherall M, McPherson KM, McNaughton HK. The effect of environment and task on gait parameters after stroke: A randomized comparison of measurement conditions. Archives of Physical Medicine and Rehabilitation. 2006; 87(7):967-73. [DOI:10.1016/j. apmr.2006.03.003] [PMID]

[41] Veerbeek JM, van Wegen E, van Peppen R, van der Wees PJ, Hendriks E, Rietberg M, et al. What is the evidence for physical therapy poststroke? A systematic review and metaanalysis. PloS One. 2014; 9(2):e87987. [DOI:10.1371/journal. pone.0087987] [PMID] [PMCID] 
This Page Intentionally Left Blank 